\title{
NEW LIVERWORTS FROM THE PERUVIAN ANDES, II. ZOOPSIDELLA GRAHAMII AND RICCARDIA GRADSTEINII (MARCHANTIOPHYTA)
}

\author{
T. Pócs \\ Botany Department, Institute of Biology, Eszterházy Károly University \\ H-3301 Eger, Pf. 43, Hungary; E-mail: colura@upcmail.hu
}

(Received: 28 March, 2019; Accepted: 14 July, 2019)

\begin{abstract}
Zoopsidella grahamii sp. nov., related to the Australasian Z. caledonica, is described from the Andes of Central Peru (Oxapampa Province) and southern Ecuador. It is distinguished from $Z$. caledonica by the smaller plant size, much lower number of lobe cells and different leaf shape, and by the much more elongate perianth mouth lobes consisting of a row of 6-7 narrowly rectangular cells. Riccardia gradsteinii sp. nov., from the same general area in Peru as Z. grahamii, is unique among all dendroid species of the genus by the broad, frilled wings of the main axis, being split into complicatedly bent and strongly crispate scales.
\end{abstract}

Key words: Andes, endemism, Lejeuneaceae, Lepidoziaceae, new species, Peru

\section{INTRODUCTION}

After the publication of our first contributions to the liverwort flora of Peru (Graham et al. 2016, Pócs 2019) within the joint project “Bryological investigation of the Central Jungle (Selva Central) Region of Peru", I have continued identifying specimens from the country and here describe two new species.

A species of genus Zoopsidella similar to the Australasian-Pacific Zoopsidella caledonica (Steph.) R. M. Schust. was recorded from the Ecuadorian Andes under that name (Benitez and Gradstein 2011). The authors noted, however, that the Ecuadorian specimens were smaller than the Australasian ones. The same plant has subsequently turned up from two different localities in the Peruvian Andes, collected by Dr James Graham (Herbario Forestal, Universidad Nacional Agraria La Molina, Lima, Peru and Field Museum, Chicago) and myself. Careful investigation of the material has shown that the Andean specimens are not conspecific with Z. caledonica and are new to science.

The pteridologist of our collecting team in 2016, Dr Carl J. Rothfels (University of California, Berkeley, CA, US), collected a plant which at first sight resembled a filmy fern. However, the lack of a vascular bundle indicated that it might be a bryophyte. Upon closer examination, it became obvious that a hitherto unknown Riccardia species, related to the widespread Neotropical $R$. fucoidea (Sw.) C. Massal., but clearly differing in having strongly crispate axial wings was at hand. 
In the following full descriptions and illustrations are given of the two species new to science.

\section{DESCRIPTION OF THE NEW SPECIES}

Zoopsidella grahamii Pócs, spec. nova

(subgen. Hyalolepidoziopsis R. M. Schust. 1972)

(Figs 1-6)

Diagnosis: Plants rostrate, whitish green, resembling the Australasian Zoopsidella caledonica (Steph.) R. M. Schust. (1969) but much smaller: shoot width 700-900 $\mu \mathrm{m}(1,200-1,350 \mu \mathrm{m}$ in Z. caledonica), stem cross section 100-120 $\mu \mathrm{m}$ in diameter (140-160 $\mu \mathrm{m}$ in Z. caledonica), lateral leaves rectangular, less than twice longer than wide (ligulate-rectangular, 3 times longer than wide in $\mathrm{Z}$. caledonica) and composed of much fewer cells (20-26, in average 22.3) than in Z. caledonica (26-33 cells, 29.9 in average). The lobes of the perianth mouth are more elongate, consisting of 6-7 narrowly rectangular, uniseriate cells (3-4 shorter cells in Z. caledonica).

Type: Dept. Pasco, Prov. Oxapampa, Distr. Huancabamba, Parque Nacional Yanachaga Chemillen, Abra Yanachaga, $10^{\circ} 23^{\prime} 15^{\prime \prime} \mathrm{S}, 75^{\circ} 28^{\prime} 10^{\prime \prime} \mathrm{W}$, alt. 2,400-2,500 m, "bosque nublado, filo de tierra firme entre 2 quebradas, sobre tronco caido", coll.: J. G. Graham, V. Coshanti, C. Mateo (AY-6/E1), 30 May 2016 (holotype: MOL).

Description: Prostrate, whitish green, translucent, in herbarium silvery, shiny, tiny plants, with irregular, ventral-intercalary branching, creeping among other liverworts on peaty soil or on decaying wood. Shoot width 700-900 (generally 800) $\mu \mathrm{m}$, stem diameter 100-120 $\mu \mathrm{m}$, consisting of 6 large hyaline cortical and several much narrower medullary cells. Ventral cortical cells 3-4, dorsal cortical cells very large, about 2 along each leaf insertion. Leaves succubous, almost longitudinally inserted, in most cases contiguous, rectangular, disk less than twice longer than wide, formed by 4 parallel, $4-5$ celled rows, bilobed with wide, U-shaped sinus. Leaf lobes consisting of 1(-2) isodiametric cells, tipped by a globose hyaline papilla. Underleaves horseshoe shaped, bilobed, consisting of only 2(-3) basal and 1-1 lobe cells, which are often capped by a hyaline papilla.

Probably dioecious, only female plants were observed. Gynoecia on short ventral-intercalary branches. Perianth subtended by several acutely bilobed bracts and bracteoles, about $1.2 \mathrm{~mm}$ long to the mouth, unistratose, with 6 lobes ending in long ciliae, formed by 6-7 narrow, elongated cells and 
sometimes ending in a hyaline papilla. Androecia and asexual propagation not observed.

With Zoopsidella grahamii the number of species in the hitherto monotypical subgenus Hyalolepidoziopsis is raised to two.

Etymology: named in honour of Dr James G. Graham, organiser of Peruvian collecting trips and collector of the type specimen.

Ecology: The new species seems to prefer decaying detritus of rotting wood or peaty soil, creeping among other acidophilous liverworts in shady, wet mossy cloud and elfin forests, above the 2,000 m elevation. It is expected from the Andes in more other localities with similar conditions, just easily escapes attention due to its small size and semi-transparent appearance, intermixed among other tiny liverworts.
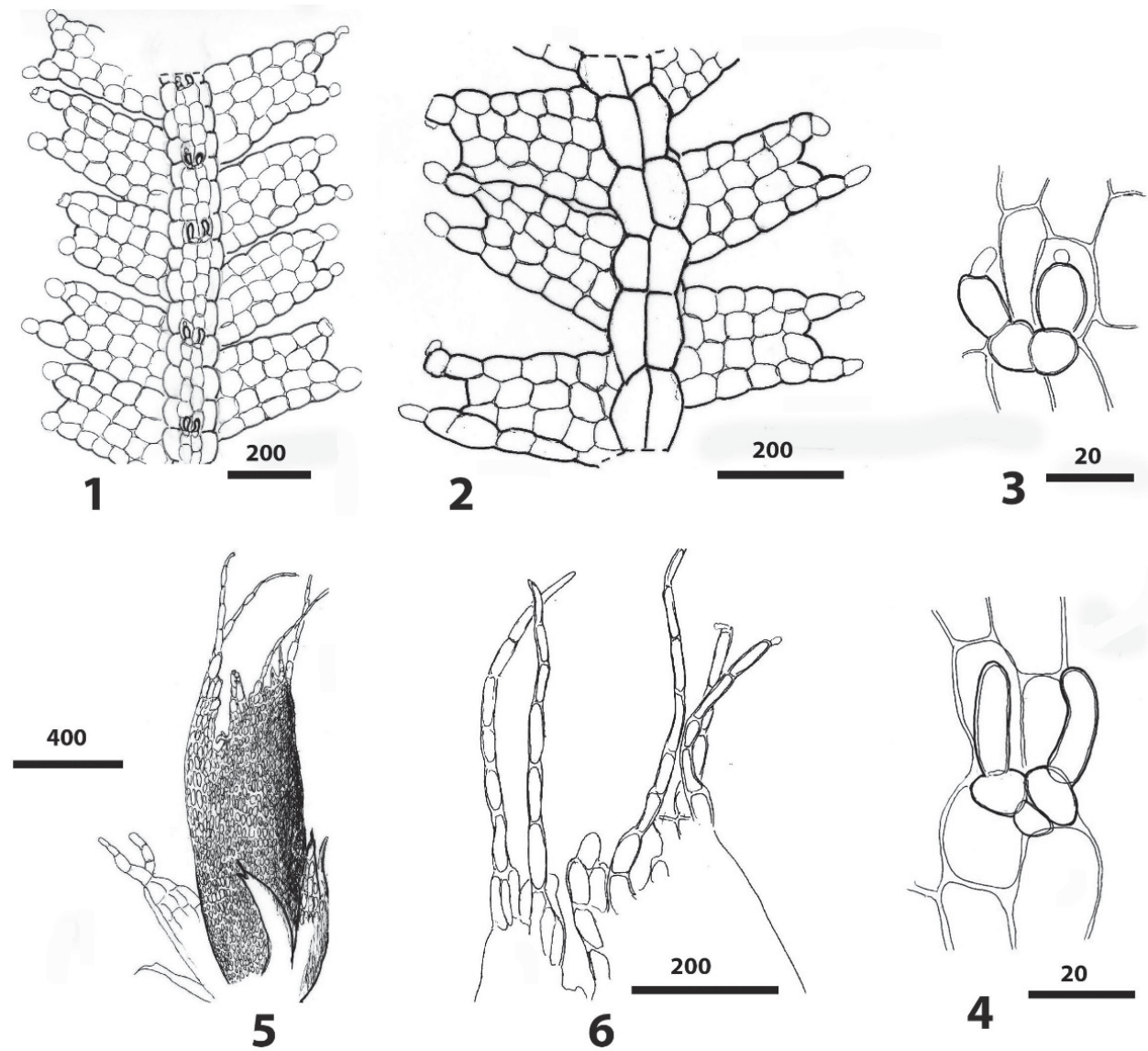

Figs 1-6. Zoopsidella grahamii Pócs, sp. nov.: 1 = habit, ventral view; 2 = habit, dorsal view; $3-4=$ underleaves; $5=$ perianth; $6=$ perianth mouth. All from the type. Scale bars in $\mu \mathrm{m}$ 
Other specimens examined: ECUADOR: Benitez and Gradstein (2011) communicated first its occurrence (under the name of Zoopsidella caledonica) from two places, collected by N. Mandl from Loja, Reserva Cerro Tapichalaca at 2,650 $\mathrm{m}$ and from Zamora-Chinchipe, Reserva Biológica San Francisco by N. Mandl et al., in both cases on the soil in cloud forests. - PERU: In the vicinity of the holotype, coll.: J. G. Graham, V. Coshanti, C. Mateo (AY-6/E1), 30 May 2016 (paratype: EGR), on detritus of rotting wood, intermixed among other liverworts, including Kurzia capillaris (Sw.) Grolle, Mnioloma caespitosa (Spruce) R. M. Schust. and Fuscocephaloziopsis crassifolia (Lindenb. et Gottsche) Váňa et L. Söderstr. Dept. Pasco, Prov. Oxapampa, Dist. Villarica, Reserva Municipal Bosque Shollet, entrando por torre mirador, $10^{\circ} 40^{\prime} 34^{\prime \prime} \mathrm{S} ; 75^{\circ} 19^{\prime} 00^{\prime \prime} \mathrm{W}$, alt. 2,399 m, "sobre tronco podrido en el bosque bajo" (elfin forest), coll.: T. Pócs (1606/YD), 17 May 2016 (paratype: EGR), on rotting wood accompanied by Kurzia capillaris, Telaranea diacantha (Mont.) J. J. Engel et G. L. Merr., Calypogeia peruviana Nees et Mont., C. rhombifolia (Spruce). Steph., Mnioloma cellulosa (Spreng.) R. M. Schust., Fuscocephaloziopsis crassifolia and Lophocolea bidentata (L.) Nees.

Riccardia gradsteinii Pócs, spec. nova

(Figs 7-18)

Diagnosis: Plants dendroid, with a creeping rhizome and an erect, terete main axis with more or less opposite branches; in size and shape similar to the widespread Riccardia fucoidea (Sw.) C. Massal. (Fig. 18) but clearly differing from the latter species by the broad, frilled wings on the main axis. Branch wings 4-10 cells broad and more or less undulate-crispate, wings on the main axis well-developed and strongly crispate, usually fragmented into separate, very complicatedly bent scales, rendering the axis a very peculiar appearance.

Type: Dept. Pasco, Prov. y Distr. Oxapampa, Parque Nacional Yanachaga-Chemillen, sector San Alberto, cordillera de Yanachaga, por sendero hacia la entrada al parque, $10.54288169^{\circ} \mathrm{S}, 75.356184840^{\circ} \mathrm{W}$. Elev. 2,560 m. Bosque nublado, sobre suelo, coll.: C. Rothfels (5135/E), 27 May 2016 (holotype: HOXA; isotypes: EGR, F, G, MOL, UC).

Description: Plants thalloid, large, 3-4 pinnate, yellowish-green, dendroid, with a short creeping rhizome, an erect main axis and more or less opposite primary branches. The rosty to chestnut brown main axis is $5-8 \mathrm{~cm}$ tall, terete and 500-800 $\mu \mathrm{m}$ (up to 40 cells) thick; axis in transversal section with a unilayered hyalodermis and a $2-4$ cells thick yellowish-brown subepidermis, which shows a gradual transition to a colourless medulla of larger cells with small trigones. Ventral side of the main axis with numerous scattered slime papilla, lateral sides with a 300-600 $\mu \mathrm{m}$ wide, strongly crispate, frilled wing emerging from the hyalodermis and usually split into separate or, occasionally, narrowly connected, complicatedly bent and acutely lobed scales. Primary branches 2-3 pinnate, terete, at the base, biconvex higher up, with a more or less continuous, 

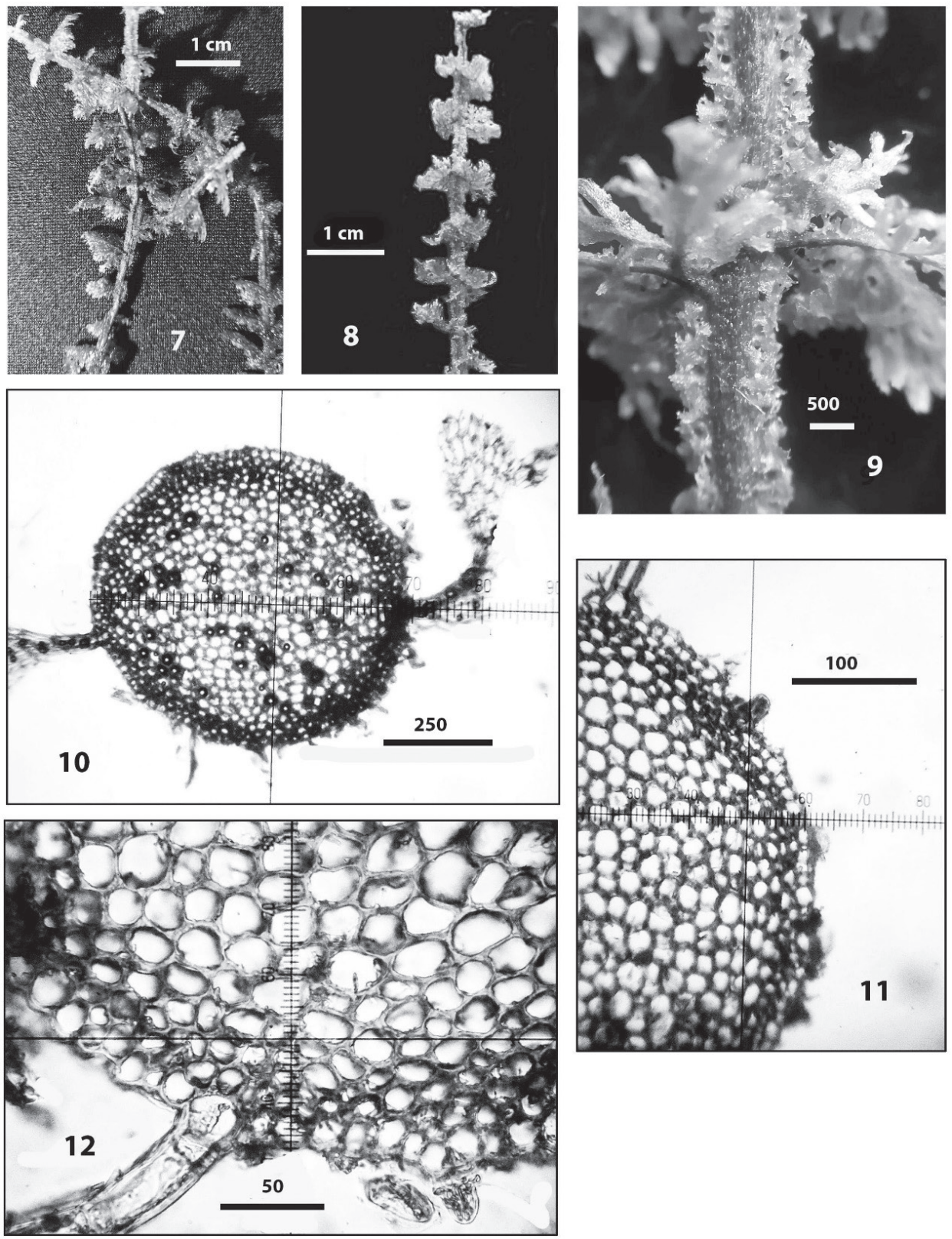

Figs 7-12. Riccardia gradsteinii Pócs, sp. nov.: 7-8 = habit, dorsal and ventral views; $9=$ detail of the main axis, with slime papillae and fragmented, frilled, crispate wings, ventral view; $10=$ cross section of the mean axis; $11-12=$ hyaloderm with cross section of wing base and with slime papillae. Scale bars in $\mu \mathrm{m}$, if not otherwise stated 
in most part undulated and crispy, dentate, $4-10$ cells wide wing. Wing cells in oblique rows, $35-50 \mu \mathrm{m}$ on branches (up to $100 \mu \mathrm{m}$ in the row along the axis), becoming smaller to the wing margin, with relatively thin, yellowish or colourless walls. Asexual reproduction and gametangia not observed.
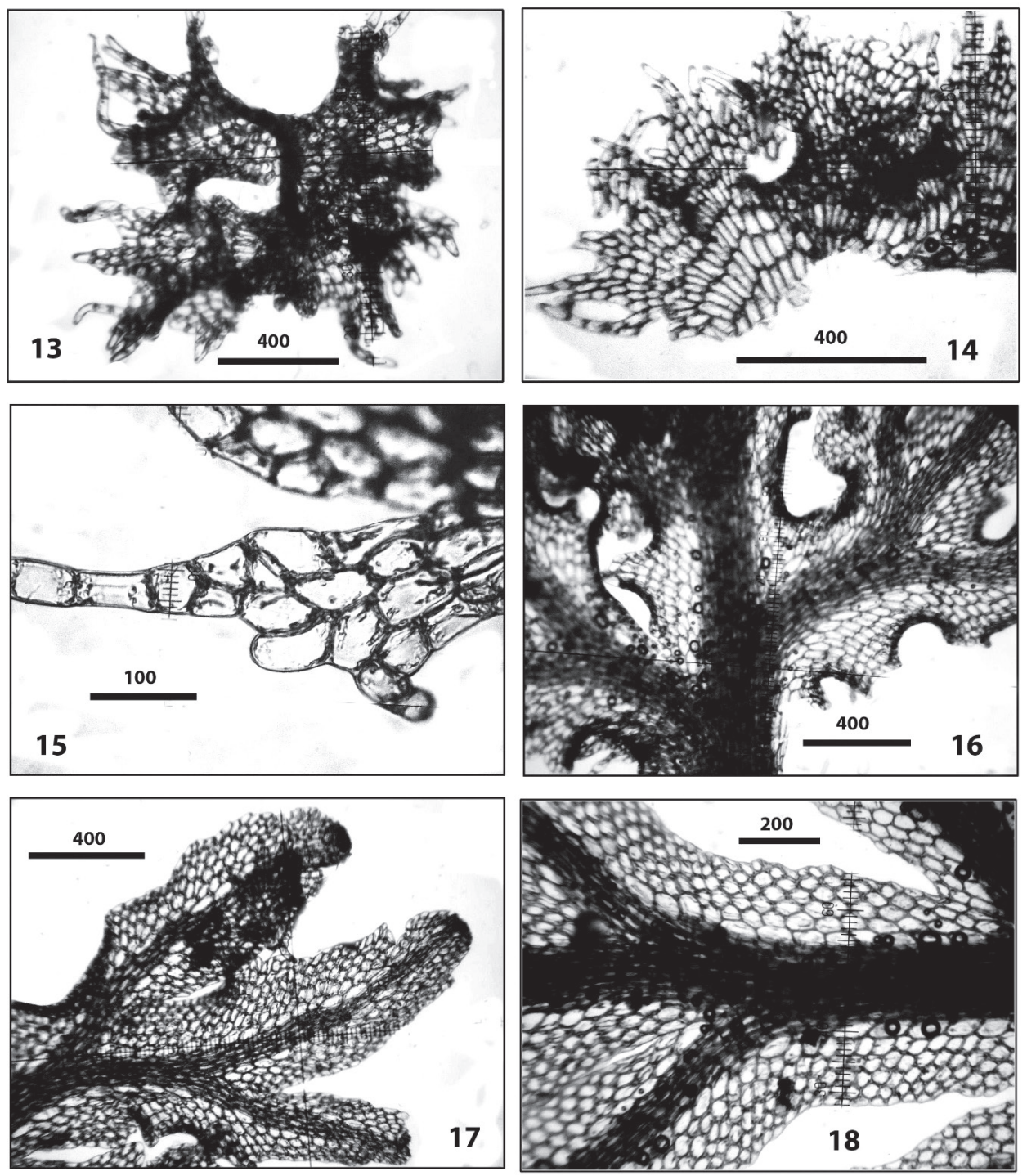

Figs 13-18. Riccardia gradsteinii Pócs, sp. nov.: 13 = axial wing scale; 14 = axial wing scales connected at the base; 15 = portion of axial wing scale; 16 = portion of axis of primary branches; $17=$ ultimate branches. All from the type. $18=$ Riccardia fucoidea (Sw.) C. Massal. portion of axis of primary branches. All from the type locality of $R$. gradsteinii. Scale bars in $\mu \mathrm{m}$ 
Etymology: The new species is dedicated to Prof. S. Robbert Gradstein (PC), renown explorer of the Andean bryophytes since decades and author of the liverwort and hornwort flora of Colombia and Ecuador (Gradstein 2019), who helped me with references and advice during the description of the new species.

Ecology: On peaty ground in upper montane cloud forest $(2,560 \mathrm{~m})$.

\section{DISCUSSION}

The tropical Andean occurrence of a Zoopsidella species belonging to the hitherto monophyletic subgenus Hyalolepidoziopsis R. M. Schust. provides a good example of Amphi-Pacific elements in Tropics (see review by Gradstein 2018). This is a relatively rare disjunct tropical distribution type much fewer in number than Afro-American, Afro-Asiatic or pantropical taxa (Gradstein 2013). The genus Zoopsidella R. M. Schust. (Schuster 1965) with its 8 (Schuster 1999, 2000) or 6 species (Söderström et al. 2016) is basically Neotropical, with the exception of Z. caledonica (Steph.) R. M. Schust., which is distributed in Australasia and the Pacific region (New Guinea, New Caledonia, Fiji and New Zealand; Schuster 1999, 2000, Engel and Glenny 2008). The centre of origin and diversity of the genus are most probably the Andes, while the sister genus Zoopsis is paleotropical with its species occurring only in Asia, Australasia and in the Pacific, not in the Neotropics. A character analysis shows intricate relationships between these two genera and with Monodactylopsis and Hyalolepidozia (Renner et al. 2006).

Schuster (1969, 1972, 1999, 2000) characterised Zoopsidella caledonica as the only species in the genus without slime papillae at leaf lobe apices. As I have found rounded slime papillae at the lobe apices of Z. grahamii (with thinner cell wall, some of them shrunken, or broken away), I suggest that the tip cell of the leaf lobes of $Z$. caledonica might also be a slime papilla, but rounded in shape, not sausage-shaped as in subgenus Zoopsidella.

Meenks (1987) recognised 36 species of Riccardia in the tropical Andes, and Rico (2006) 22 in Venezuela. Many of these, however, were placed in synonymy by Gradstein and Reeb (2018) who accepted 14 species in Columbia and Ecuador. Riccardia gradsteinii stands isolated among the tropical Andean species, and in the genus as a whole, by its strongly crispate, frilled and fragmented axial wings. In plant habit and in the broad branch wings made up of large cells, the new species resembles the common neotropical $R$. fucoides However, the main axis in the latter species is wingless or with a narrow, rudimentary wing only, and the branch wings in are never undulate-crispate (Gradstein and Reeb 2018). Protuberances on the main axis are seen in some southern temperate species, as Riccardia prehensilis (Hook. f. et Tal.) C. Mas- 
sal., R. eriocaula (Hook.) Besch. et C. Massal., R. fuegiensis C. Massal., R. spinulifera C. Massal. (Brown and Braggins 1989, Hässel 1972). But these axial outgrowths are not of wing origin and are morphologically totally different from those of $R$. gradsteinii.

The two new species contribute to the large number of Andean endemics.

Acknowledgements - I thank the opportunity to study the liverwort material collected by Dr James G. Graham and by Dr Carl J. Rothfels. I would like to express thanks for the financial and logistical support of Field Museum, Chicago (F), namely to Dr Matt von Konrat, Head of Botanical Collections, Bryophytes and Pteridophytes; to Herbario Forestal in Molina (MOL), Herbario Selva Central in Oxapampa (HOXA), the Eszterházy Károly University, Eger (EGR) and the Hungarian Academy of Sciences. Special thanks are due to Prof. Stephan Robbert Gradstein (PC) for his useful advice on the new species.

\section{REFERENCES}

Benitez, A. and Gradstein, S. R. (2011): Adiciones a la flora de briófitas del Ecuador. - Cryptogamie, Bryol. 32: 65-74. https://doi.org/10.7872/cryb.v32.iss1.2011.065

Brown, E. A. and Braggins, J. E. (1989): A revision of the genus Riccardia S. F. Gray in New Zealand with notes on the genus Aneura Dum. - J. Hattori Bot. Lab. 66: 1-132.

Engel, J. J. and Glenny, D. S. (2008): A flora of the liverworts and hornworts of New Zealand, Volume 1. - Missouri Botanical Garden, St. Louis, 897 pp.

Gradstein, S. R. (2013): Afro-American hepatics revisited. - Polish Bot. J. 58(1): 149-177. https://doi.org/10.2478/pbj-2013-0016

Gradstein, S. R. (2018): Amphi-Pacific tropical disjunctions in the bryophyte floras of Asia and the New World. - Philipp. J. Syst. Biol. 12(1): 1-11. https://doi.org/10.26757/ pjsb.2018a12012

Gradstein, S. R. (2019): The liverworts and hornworts of Colombia and Ecuador. - Mem. New York Bot. Garden (in press).

Gradstein, S. R. and Reeb, C. (2018): The genus Riccardia (Aneuraceae) in Colombia and Ecuador. - Cryptogamie, Bryol. 39(4): 515-540. https://doi.org/10.7872/cryb/v39. iss4.2018.515

Graham, J. G., Fischer, M. and Pócs, T. (2016): Bryoflora and landscapes of the eastern Andes of central Peru: I. Liverworts of the El Sira Communal Reserve. - Acta Biol. Plant. Agriensis 4: 3-60. https://doi.org/10.21406/abpa.2016.4.3

Hässel, G. G. (1972): Revisión taxonómica del genero Riccardia (Hepaticae). Especies andinopatagonias y subantarticas incluyendo las Islas Juan Fernandez, Malvinas, Georgias del Sur, etc. - Revista Mus. Argent. Cienc. Nat. "Bernardino Rivadavia" Inst. Nac. Invest. Cienc. Nat., Cienc. Bot. 4(1): 1-242.

Meenks, J. (1987): Studies on Colombian cryptogams XXVIII. A guide to the tropical Andean species of Riccardia (Hepaticae). - J. Hattori Bot. Lab. 62: 161-182.

Pócs, T. (2019): New liverworts from the Peruvian Andes I. Colura ochyrana and Drepanolejeunea halinae (Lejeuneaceae, Marchantiophyta). - Acta Mus. Siles. Sci. Natur. 68(1-2): 37-44. https://doi.org/10.2478/cszma-2019-0005 
Renner, M. A. M., Brown, E. A. and Glenny, D. S. (2006): Two new Zoopsis species and their relationships to other zoopsids (Jungermanniopsida: Lepidoziaceae). - J. Bryol. 28(4): 331-344. https://doi.org/10.1179/174328206x136278

Rico, G. R. (2006): Inventario preliminar de la familia Aneuraceae en Venezuela. - Bryoph. Div. Evol. 27(1): 45-50.

Schuster, R. M. (1965): Studies on hepaticae. XXVI. The Bonneria-Paracromastigum-Pseudocephalozia-Hyalolepidozia-Zoopsis-Pteropsiella complex and its allies - a phylogenetic study, part 1. - Nova Hedwigia 10(1-2): 19-61.

Schuster, R. M. (1969): Problems of the antipodal distribution in lower land plants. - Taxon 18(1): 46-91. https://doi.org/10.2307/1218591

Schuster, R. M. (1972): Phylogenetic and taxonomic studies in Jungermanniidae. - J. Hattori Bot. Lab. 36: 321-405.

Schuster, R. M. (1999): Studies on hepaticae LXVI. Lepidoziaceae subfamily Zoopsidoideae (3): Zoopsidella. - Nova Hedwigia 69(1-2): 101-150.

Schuster, R. M. (2000): Austral hepaticae. Part 1. - Beih. Nova Hedwigia 118: 1-524.

Söderström, L., Hagborg, A., von Konrat, M., Bartholomew-Began, S., Bell, D., Briscoe, L., Brown, E.t, Cargill, D. C., Costa, D. P., Crandall-Stotler, B. J., Cooper, E. D., Dauphin, G., Engel, J. J., Feldberg, K., Glenny, D., Gradstein, S. R., He, X. H., Heinrichs, J., Hentschel, J., Ilkiu-Borges, A. L., Katagiri, T., Konstantinova, N. A., Larraín, J., Long, D. G., Nebel, M., Pócs, T., Puche, F., Reiner-Drehwald, M. E., Renner, M. A. M., Sass-Gyarmati, A., Schäfer-Verwimp, A., Segarra Moragues, J. G., Stotler, R. E., Sukkharak, P., Thiers, B. M., Uribe, J., Váňa, J., Villarreal, J. C., Wigginton, M. J., Zhang, L. and Zhu, R.-L. (2016): World checklist of hornworts and liverworts. - PhytoKeys 59: 1-828. https://doi.org/10.3897/phytokeys.59.6261

Open Access statement. This is an open-access article distributed under the terms of the Creative Commons Attribution 4.0 International License (https://creativecommons.org/ licenses/by/4.0/), which permits unrestricted use, distribution, and reproduction in any medium, provided the original author and source are credited, a link to the CC License is provided, and changes - if any - are indicated. (SID_1) 
